\title{
German Studies in Australia: A Question of Interdisciplinarity
}

\author{
Tim Mehigan (Otago)
}

"Interdisciplinary" is now almost an old term. When we thought we knew what disciplines were, that is, more or less clearly defined fields of specialty marking off one scholarly domain from another, the adjective "interdisciplinary" was invoked to describe what we thought we did when we moved between them. For a long time, it was neither fashionable nor advisable to do so. Methodological principles borrowed from outside a discipline area were not readily understood within it, nor were they readily commanded. Using them meant not only complicating the approach to a text, but also, perhaps, mixing up genres and text types, with the attendant risk of conferring on the practice of scholarship an unscientific appearance.

That science was important in an age of disciplines is a nineteenth century idea, ${ }^{1}$ and arose after the decline of a still older idea, that of humanism. ${ }^{2}$ Scientific principles in the arts and humanities entered the mainstream, along with the concept of the expert, ${ }^{3}$ around the turn from the nineteenth to the twentieth century, when a new revolution in science began to revise the understanding of Newton's fixed time-space continuum, and neo-Kantianism became established in European universities. Where, in the age of humanism, we had once read literature for instruction about our moral selves (an idea closely associated with the name

\footnotetext{
${ }^{1}$ One of the first promoters of the value of science for a study of humanity was Auguste Comte in the early to mid nineteenth century. Comte put forward the idea of a new social science in response to the political turmoil of Europe in the first half of the nineteenth century. Cf. Nasser Behnegar: Leo Strauß, Max Weber, and the Scientific Study of Politics. Chicago and London: University of Chicago Press 2003, 9-10.

${ }^{2}$ Under the humanist paradigm, literary criticism represented a foundational discourse that sought to set parameters for the process of interpretation from a metaphysical standpoint: cf. Gerald Graff: Professing Literature. An Institutional History. Chicago and London: The University of Chicago Press 1987, 252-4.

${ }^{3}$ Cf. Jürgen Habermas: "Die Moderne: Ein unvollendetes Projekt." In: J. H.: Die Moderne. Ein Unvollendetes Projekt. Philosophisch-politische Aufsätze. Leipzig: Reclam 1994 (first published 1981), 51.
} 
of Matthew Arnold in English-speaking countries ${ }^{4}$ ), we soon came to read literature for knowledge of discrete and concrete "things": things like how our society came into being, how our institutions were constructed, and what assumptions had shaped our thought. At this time, the humanities underwent a mini-revolution: sociology, issuing from Comte's positivism in the mid nineteenth century and the upsurge of interest in questions of social evolution, industrialisation and population in the late nineteenth century, was developed to understand our social selves and literature was studied as "Geistesgeschichte" in pursuit of an understanding of our mental selves. ${ }^{5}$ It was typical that linguistics was born at this time, de Saussure's science of signs, semiotics, discovered, and Darwinian biology propagated as the ultimate material statement about our social origins.

Somewhere in the middle of this period another discrete academic "thing" arose and began to flourish: the languages of the societies we especially wished to relate to. ${ }^{6}$ One of these languages was German, a language we read principally for knowledge of the German nation and the German people, and not because we fervently desired to speak it. Under the regime that held sway in the academy of this intermediate period, it

\footnotetext{
${ }^{4}$ See, e.g., his Culture and Anarchy. An Essay in Political and Social Criticism. London: Smith, Elder and Co. 1875 (second edition). Achatz von Müller traces the moral idea of the humanities back to notions of a sacro egoismo expounded by the Scottish philosopher Adam Smith in the eighteenth century. The moral function of the humanities was both to enhance and to delimit possibilities associated with the breakthrough to a new idea of economic and social competitiveness based on the "Gesetz des Egoismus." Cf. "Selige Apathie: Welchen Nutzen haben Germanistik, Philosophie oder Kunstgeschichte? Die Geschichte einer falsch gesteliten Frage." Die Zeit, 18 (22 April 2004), 47.

${ }^{5}$ Philosophy, by this time, however, was moving in a different direction. At the start of the twentieth century, ideas advanced by Georg Simmel - though they were to meet opposition from Ernst Bloch and others - already indicated "eine Riickwendung der Philosophie auf konkrete Gegenstände." Cf. Theodor Adorno: "Henkel, Krug und frühe Erfahrung." Th. A.: Noten zur Literatur IV. Frankfurt/Main: Suhrkamp 1974, 93, 103.

${ }^{6} \mathrm{Cf}$. Claire J. Kramsch: "Language Acquisition and Language Learning." Introduction to Scholarship in Modern Languages and Literatures. Edited by Joseph Gibaldi. New York: The Modern Language Association of America 1992, 53-76. Kramsch observes: "At a time when language study was closely linked to philology and phonetics, European scholars such as Henry Sweet, Harold Palmer, Otto Jespersen, and Wilhelm Vietor attempted to apply the findings of the linguistic sciences to language teaching. Despite developments in linguistic thought in the 1920s and 1930s, however, no theoretical foundation was established for language teaching before 1940, and questions about what it means to acquire, learn, and know a language did not get addressed before the 1960s" (55).
} 
was sufficient to command a few phrases in German (no matter the accent we used in reproducing it), since it was the written form of the German language we were mainly interested in. Our - not yet wholly scientific, but no longer wholly moral - notion was to "read through" the literature of language to the society that lay behind it. Small wonder, therefore, that this increasingly social and sociological approach to reading literature became grist to the mill of Marxists, who, by the mid to late sixties were beginning to rise to prominence in universities around the world after the complete failure of the humanist idea by the end of the Second World War. ${ }^{7}$ As new discipline areas were marked out, so were the methods that underlay them. This was the period when literature was either "aesthetically compromised" and "bourgeois" or "dogmatically compromised" and "ideological." The Lukács-Adorno debate of the 1950s about modernist European literature, ${ }^{8}$ in which these terms were deployed, was felt here in Australia as well, albeit with different players and with somewhat of a time lag. In Australian universities in the late sixties and early seventies, these debates led to a massive schism between the Sydney and Melbourne English departments, which gave the lead in those days in questions of the theory of literature. ${ }^{9}$

Yet the idea of the new humanities that became associated with "Geistesgeschichte," feeding in the sixties on existentialist hermeneutics in the West and historical materialism in the East, declined just as swiftly as it arose. A factor contributing to this decline was a problem with the idea of science on which "Geistesgeschichte" rested. According to this idea of science, a literary work of art could be known and made utterly known to

\footnotetext{
${ }^{7}$ Karl Popper refers to the importance of this failure in his volume of essays The Myth of the Framework: In Defence of Science and Rationality. London: Routledge and Kegan Paul, 1994 and his more programmatic work The Open Society and its Enemies. London: Routledge and Kegan Paul 1962.

${ }^{8}$ See Georg Lukács: "Die Gegenwartsbedeutung des kritischen Realismus." G. L.: Probleme des Realismus I: Essays ïber Realismus. Neuswied/Bern: Luchterhand 1971, first published 1958, 457-603, and, for Adorno's reaction, Theodor W. Adorno: "Erpreßte Versöhnung. Zu Georg Lukács 'Wider den mißverstandenen Realismus,'” in Th. A.: Noten zur Literatur II. Frankfurt/Main: Suhrkamp 1979, first published 1958, 152-187. For an assessment of the importance of this debate for modernist literature, cf. Stephen D. Dowden: Kafka's Castle and the Critical Imagination. Columbia, SC: Camden House 1995, p. 55f.

${ }^{9}$ Cf. Andrew Riemer: Sandstone Gothic. St Leonards, N.S.W.: Allen and Unwin 1998.
} 
others by a complete familiarity with its context. Under such "positivistic" notions of literary history, the context of a particular work of art could be drawn out and made intelligible by understanding the historical, biographical and aesthetic circumstances that had informed it. The question of whether the context of a work of art can be utterly known, as we now appreciate with the benefit of hindsight, has been revealed as one of the many blind-alleys characterizing the literary enterprise. When Gero von Wilpert came to the University of Sydney in the early 1980 s to take up a Chair of German, he already talked scathingly - and, as I now see, correctly - of "Geistesgeschichte" as a "Geistergeschichte," for indeed by then, for all those who had eyes to see it, "Geistesgeschichte" was already only a ghost of an idea. It had stolen away from under our noses sometime over the previous twenty years. If the rise of social criticism and then cultural critique in European and American literary studies were signs of an imminent departure, ${ }^{10}$ the first stirrings of "postmodernism" in the early seventies already signified that "Geistesgeschichte" had indeed gone all metaphysical on us and "transubstantiated" - very much its agenda from the beginning. ${ }^{11}$

With it went, in Australia at least, the consciousness of what the discipline of German Studies could reliably be taken to mean. In fact, nowadays we can no longer speak of German Studies in Australia as a discipline at all in the traditional sense of the word, even if it still has a practice that is debated at conferences. A measure of this change is the fact that chairs of German, once established in every mainland state of

\footnotetext{
${ }^{10}$ Allan Janik and Stephen Toulmin's 1973 study of the philosophical-cultural significance of Vienna at the turn to the twentieth century remains a classic example of cultural critique. Cf. Allan Janik, Stephen Toulmin: Wittgenstein's Vienna. New York, London: Touchstone 1973.

"That the adherence to notions of "Geistesgeschichte" is still strong can be read into Martin Seel's recent article in Die Zeit. The humanities, Seel argues, are concerned with a type of understanding that helps us understand. In doing so, the humanities plug gaps in other branches of knowledge that only offer particular perspectives about the world. Accordingly: "Ein Vorrat an Verständnis und die Bemühung um Verstehen sind das Normalste von der Welt, weil aus ihnen die menschliche Welt besteht. Wer die Fähigkeit der verstehenden Orientierung hat, ist konventionell gesprochen in der Welt des Geistes zu Hause." Martin Seel: "Weltverstrickt: Das Verstehen verstehen. Über den Sinn der Geisteswissenschaften." Die Zeit 18 (22 April 2004) 48.
} 
Australia and in Tasmania and in every larger university, have all but vanished. The rise of schools of languages within the university and other groupings that subsume the old discipline of German Studies within it represents another measure. My argument, therefore, is not only that the discipline of German Studies no longer exists in Australia in any accepted sense of the world, but also that everything we do in German Studies in this most recent phase of our scholarly development can lay some claim to being interdisciplinary. Roland Barthes addressed a similar question when he sought to define the term "interdisciplinary" in his From Work to Text:

Interdisciplinary work is not a peaceful operation: it begins effectively when the solidarity of the old discipline breaks down - a process made violent, perhaps, by the jolts of fashion - to the benefit of a new object and a new language [i.e. discourse], neither of which is in the domain of those branches of knowledge that one calmly sought to confront [...] [T] here now arises a need for a new object, one attained by the displacement or overturning of previous categories. $^{12}$

I endorse this view of the term "interdisciplinary," but with this rider: no new "solidarity" actually emerges. For in the most recent phase of institutional development, at least in Australia, the link between discipline and department - once an unbreakable alliance - has been severed, and not just once, but repeatedly. Thus it has been the fate of virtually every academic unit in Australia where German has been taught to have been absorbed into departments with allegedly kindred, but, in fact, often strikingly inappropriate, companion languages (for example, "Germanic Studies and Russian"), then into still larger language groupings (e.g. "School of European, Asian and Middle Eastern Languages"), and latterly into larger groupings again, this time with the optional addition of linguistics and applied linguistics (e.g. "School of Languages"). Each new

${ }^{12}$ Quoted in: Giles Gunn: "Interdisciplinary Studies." Introduction to Scholarship in Modern Languages and Literatures. Edited by Joseph Gibaldi. New York: The Modern Language Association of America 1992, 244. 
iteration in the structure within which German Studies is administered has diluted the financial circumstances underpinning German Studies, interpolated more and more layers of bureaucracy, and alienated the logistical support the discipline of German Studies receives for its activities to the point where there is no longer any sense of certainty that the local administrative assistant commands any knowledge of the German language. The situation that still obtains in German universities - that at least one secretary is assigned to discharge the administrative activity of a chair of German, with several chairs in one department - is as remote to life here as one solar system is from another. In this sense, we are indeed entitled to speak, as is now de rigeur, of an "Auslandsgermanistik.",13

This already suggests that we in Australia are in the grip of a serious and protracted crisis affecting what we do, and, indeed, this is so obviously the case that repeating this here will serve no useful purpose. More productive is a new and urgent question already alluded to, namely, that in this brave new world of German Studies in Australia - caught between the decline of the scientific idea of the discipline, on the one hand, and the emergence of a new notion of "interdisciplinarity" reaching across all parts of modern faculties of arts, on the other - we not only have to alter our teaching and research practice, but, curiously and disturbingly, we have neither training nor competence to do so. Julia Kristeva reminds us of this when she said in a recent interview:

Interdisciplinarity is always a site where expressions of resistance are latent. Many academics are locked within the specificity of their field; that is a fact. Even if they demonstrate or manifest a desire to work with other disciplines, more often than not it turns out that, in fact, the work undertaken fails to break new ground.

\footnotetext{
${ }^{13}$ For a recent use of this term, see Linguistik im DaF-Unterricht: Beiträge zur Auslandsgermanistik. Edited by Peter Colliander. Frankfurt/Main: Peter Lang, 2001.
} 
Thus, the first obstacle is often linked to individual competences coupled with a tendency to jealously protect one's own domain. ${ }^{14}$

I would go further than Kristeva and say that "jealously protecting our domain" in this country has corrupted what we do to the point of extinction. Very few German Studies sections in Australia, for example, now mention Goethe and Schiller and Weimar Classicism to their students, let alone teach them. Indeed, it is rare to engage in German literature of any type antecedent to the twentieth century, and even discussing themes of the period before the fall of the Berlin wall can, from a student's point of view, raise a sceptical eyebrow. Our response to these emerging pedagogical issues in the intermediate phase, I have argued, was to turn to the "disciplinarity" of the age of science and make German linguistics and second language acquisition on one side, and variant forms of social criticism, including cultural critique and feminist studies, on the other, the main occupation. Film studies in German - as a type of transposed literary studies - became another substitute, but only in a very small number of universities in Australia. ${ }^{15}$ And as we practise the new German Studies within strategic political groupings we do not desire, much less love, the uneasy feeling arises that even these new alliances in "schools of languages" or "languages, linguistics and cultures" may soon be overtaken by stranger and more wonderful administrative partnerships that may plunge us into renewed crisis. It behoves us, in the middle of this institutional change, to develop our professional ethic, and to reestablish our professional association with one another.

So the problem, as I see it, is that we have retooled to meet the challenges of the age of disciplines, and now must retool to meet the challenge of the age of interdisciplinarity. Foreign language is no longer pursued for knowledge of society, or of language "as such," and if we only do foreign language acquisition we will become not just "schools of

\footnotetext{
${ }^{14}$ Julia Kristeva: "Institutional Interdisciplinarity in Theory and Practice. An Interview." The Anxiety of Interdisciplinarity. De-, dis-, ex-. Edited by Alex Coles and Alexia Defert. Volume 2. London: BACKless Books 1998, 6.

${ }^{15}$ Film studies feature as an important adjunct part of the German Studies curriculum at the Australian National University, Canberra and Newcastle University in New South Wales.
} 
languages," but Berlitz schools of language, just as we were beginning to lay the bogey of the functional "service" requirement for other areas of the arts faculty to rest. ${ }^{16}$ Since language is now culture, and culture is by definition "interdisciplinary" (even as "interdisciplinary studies is not a field", as Giles Gunn has said in a recent essay on this theme ${ }^{17}$ ), the practice of foreign language sections in general and German Studies sections in particular must change, and in some areas, fundamentally.

But change to what? What I am suggesting is that we have to reconceive the German Studies curriculum. I quote Julia Kristeva again:

One cannot be an amateur, or decide one day 'Let's be interdisciplinary.' A university may decide to develop in that direction,

\footnotetext{
${ }^{16}$ This service function argument about foreign languages implies that the study of languages is a purely formal undertaking with a low intellectual content. Yet it is incontrovertibly the case that many of the greatest philosophical minds were and are also great linguists. Foreign language facility and intellectual endeavour, in other words, have always gone hand in hand. The philosophy of, say, Jacques Derrida and Martin Heidegger, would not have been possible without a profound knowledge of Latin and ancient Greek, and the Algerian-born Frenchman Derrida, like Barthes and Foucault before him, displays a deeply nuanced understanding of German that has brought alive for him German thought with a complexity few have ever commanded before him. This is by no means an isolated example. What has come down to us as French post-structuralism, largely through the work of Barthes, Foucault and Derrida, but also Lacan, Lyotard, Greimas and Kristeva, took root in scholarship that is strikingly multi-lingual in outlook. And the French have been acute readers of the work of their neighbours, particularly the Germans. Where others neglected the German tradition of ideas in the politically charged early postwar period and failed to read those philosophers like Heidegger and Nietzsche considered politically suspect, these French scholars began to interpret a tradition of ideas that even most Germans themselves neglected in the politically charged environment of the immediate postwar world. Not for the first time, therefore, it was the foreigner who was to bring a nuanced understanding of indigenous culture to a wider audience. My "take" on the question of the intellectual aspects of language study in a university setting, then, is that it is mainly a non-issue for the insider, who is always already cognisant of the profound emotional and intellectual boundaries to be crossed in language study and skills transfer at the higher and highest levels, but who, nevertheless, must never shrink from the task of convincing outsiders that such is the case. At a time of peer-reviewed quality assessment, such as that prescribed under the performance based review process currently underway in countries like New Zealand, it is now incumbent upon language scholars of every kind to demonstrate the rich intellectual nature of language scholarship, be it by empirical studies in linguistics, foreign language pedagogy and computer assisted language learning, or conceptually-based or author-based interpretations in cultural and literary studies. Today, more than ever, intellectual content, as well as utility and relevance, must be demonstrated within a wider institutional framework.

${ }^{17}$ Gunn (1992) 239.
} 
but what matters is that each researcher finds and establishes some complicities with other researchers so that interdisciplinarity comes from the base of the pyramid and works its way up. [...] One can only benefit from interdisciplinary practices if researchers meet other researchers whilst learning how to discuss their competences and the outcome of their interaction; therefore contributing to the exposure of the risks inherent in an interdisciplinary practice. $^{18}$

Interdisciplinarity does not just occur on our side of the fence; it has become a fact of life for our students, who recognise no loyalty to a discipline area, only a self-imposed duty to acquire enough marketable skills to earn a living. Our enrolment practices already suggest this. Students enrolled in pure arts degrees now make up less than fifty per cent of our clientele. ${ }^{19}$ More and more students do combined degrees arts and engineering, arts and science, arts and law, but also musicscience (i.e. not "arts" at all!) - and an increasing number come to us from different universities down the road where they might be studying tourism or journalism. The "diploma in modern languages" 20 at the University of Melbourne is about seven or eight years old, and now indicates that we often do not teach degree students of German at all. For these students, German is a subsidiary skill they connect, often wondrously, with their main specialty. This means that when they enter our courses, they are not seeking to hear about the literary debates within our old discipline, nor even the linguistic ones. They want to know about what German culture is, how they can access it better, how they can speak German well, as quickly as possible. Most have no interest in taking more than three years of German, and even third year numbers in post-matriculation streams have sunk to dangerously low levels across Australian universities. Moreover, less than five, and frequently no more than two, percent of students

\footnotetext{
${ }^{18}$ Kristeva (1998) 6.

${ }^{19}$ This is the figure at the University of Melbourne. It is part of similar trends around Australia.

${ }^{20}$ The diploma in modern language allows students to complete a course of study in a language that is less than the requirement for a major. The diploma constitutes roughly fourfifths of the normal coursework requirement for a major.
} 
beginning a course of study in German will progress to complete an honours year of study in German (those who take a fourth year of German and write a thesis on a German topic).

The situation facing Australian German Studies sections and the nature of its student clientele is therefore this: students must be offered as many points of connection with their specialties as possible, and students must be invited to consider the benefits of in-depth knowledge of the German language and culture at every level of our offerings. This may tax our conviction about the old discipline of German Studies, which was based on a wholly different set of "scientific" assumptions, yet, I believe and hope, it doesn't exhaust them - indeed it must not. I am talking about a new theory and practice of German Studies. From my own angle as an only partly reconstructed student of literature, it means discovering the interdisciplinary quality of a broadly understood "linguistic culture" in German Studies. It means returning to an understanding of the values of German culture that made and still makes that culture distinctive in global terms. One of many highpoints was the experiment in German thought in the eighteenth century that ended in the achievement of Weimar Classicism. So we should start to talk to our students again about Schiller and Goethe, not in literary-aesthetic, but in linguistically informed cultural terms. It means telling the students about the way the ideas of Marx, Nietzsche and Freud - the names they have all heard about - established modern life through a process of revolt against aspects of this same cultural tradition. It means talking about Romanticism not as a rather remote aestheticism, but, as Hemingway said in a different context, as "a theory, like another," albeit a holistic theory that lives on in debates about global culture, ethics and ecology. ${ }^{21}$ It means casting aside the fashionable denigration of European theories, and, against the trend towards the Asia-

\footnotetext{
${ }^{21}$ This also appears to be what Andrew Bowie has in mind when he observes: "There are signs that the long-term decline of German studies might be partly arrested if a Romantic combination of different literary, cultural, historical and philosophical approaches became the norm." Cf. Andrew Bowie: Aesthetics and Subjectivity. From Kant to Nietzsche. Manchester and New York: Manchester University Press 2003, vii-viii.
} 
Pacific in our own region, ${ }^{22}$ of rediscovering an interest in Europe (which is, after all, Australia's largest single trading partner). It means spreading both Europhilia ${ }^{23}$ as well as Germanophilia. It means crossing discipline boundaries to remind students that Germany gave the world not just the "Copernican revolution" in thought through Kantian philosophy, but a second "Copernican revolution" in the form of Einstein's theory of relativity and Heisenberg's uncertainty principle. Another discipline boundary we must cross leads in the direction of psychology, not only because the unconscious is a German invention (invented by German Romanticism a hundred years before Freud), but also because the German mind gave the world "Gestalt" theory, which has been influential in a range of disciplines from psychology through to architecture. If "culture" was a notion that widened ideas to the point where - under modern notions of cultural studies - they could be robbed of their linguistic-cultural roots, we must rob them back into a reconceived German Studies curriculum that discusses the German contribution to thought within a wider historical, anthropological and language-related cultural framework that is much more than the disembodied and linguistically de-contextualised cultural studies taught in today's English departments. One such framework could be European studies, so long as this is taken to mean an inventory of social, political and economic ideas that have come to shape the shared cultural heritage of Europe, rather than just a dialogue about treaties and institutions from Maastricht to the present day.

The new way of interdisciplinarity, therefore, will throw up enormous intellectual challenges for German Studies in the future. It will require German Studies sections to be more outwardly focused than they have been hitherto, more sensitive to the vocational needs of student-clients,

\footnotetext{
${ }^{22}$ One of the key proponents of the orientation towards Asia in Australia was the former Prime Minister of Australia, Paul Keating, who argued that when Britain chose not to send reinforcements to support the defense of Singapore in 1942 - this was a formidable force of 90,000 British, Australian and Indian troops defending it against the advancing Japanese - it had also chosen to abandon the region. Australia had had no choice but to cultivate an alliance with the United States and begin to develop its own understanding of his place in the Asia-Pacific. The final moment when the umbilical cord was cut occurred when Britain joined the European Economic Community in January 1973.

${ }^{23}$ A term also used by Kristeva: (1998) 14.
} 
more strategic in the establishment of alliances within faculties of arts and humanities. Reflection on the value and utility of linguistically founded cultural theory and practice will become a mainstay of this approach to German Studies. Failure to build such outward focus, however, will result in the increasing insularity of narrowly defined German Studies programmes and their progressive marginalisation as specialist language training centres within the academy. The intellectual work, in that case, will be left to others. Yet it is precisely in the crossover between sophisticated cultural understanding and the special quality of language proficiency that language departments of all persuasions can maintain not only their relevance within the modern university, but also their importance in the global community of the future. As Andrew Bowie notes in the specific case of German culture: "Germany is, after all - even though the contemporary state of the humanities would not suggest it - the main source of nearly all the major recent theoretical directions in the humanities."24 Language facility, in other words, is still the sine qua non of cultural understanding about our world, today more than ever.

${ }^{24}$ Bowie (2003) viii. 